OPEN ACCESS

Citation: E. Ansari, M. Khosrowshahli, A. Ashraf Jafari, A. Etminan (2021) Induction of Autotetraploidy and its effects on morphophysiological traits in some annual and perennial medics. Caryologia 74(1): 75-82. doi: 10.36253/caryologia-809

Received: January 03, 2020

Accepted: April 26, 2021

Published: July 20, 2021

Copyright: (c) 2021 E. Ansari, M. Khosrowshahli, A. Ashraf Jafari, A. Etminan. This is an open access, peer-reviewed article published by Firenze University Press (http://www.fupress.com/caryologia) and distributed under the terms of the Creative Commons Attribution License, which permits unrestricted use, distribution, and reproduction in any medium, provided the original author and source are credited.

Data Availability Statement: All relevant data are within the paper and its Supporting Information files.

Competing Interests: The Author(s) declare(s) no conflict of interest.

\section{Induction of Autotetraploidy and its effects on morphophysiological traits in some annual and perennial medics}

\author{
Elham Ansari ${ }^{1}$, Mahmood Khosrowshahli ${ }^{2}$, Ali Ashraf Jafari ${ }^{3}$, \\ AlireZa ETMinAN ${ }^{4}$ \\ ${ }^{1}$ PhD student, Department of plant breeding, Islamic Azad University, Science and \\ Research Branch, Tehran, Iran \\ ${ }^{2}$ Department of plant breeding, Islamic Azad University, Science and Research Branch, \\ Tehran, Iran \\ ${ }^{3}$ Research Institute of Forests and Rangelands, Agricultural Research Education and \\ Extension Organization (AREEO), Tehran, Iran \\ ${ }^{4}$ Department o plant breeding, Islamic Azad University Kermanshah Branch, Kerman- \\ shah, Iran \\ *Corresponding author. E-mail: mkhosrowchahli@yahoo.com
}

\begin{abstract}
In order to study of the effects of polyploidy on morph-physiological traits in some annual and perennial medics, five annual and three perennial diploid medics were subjected to different concentrations of colchicine solution $(0.1 \%, 0.5 \%, 1 \%$ and $2 \%$ ) in mitosis stage. The induced tetraploids were identified by counting stomata guard cells chloroplasts. The highest survival rate and tetraploidy induction with average values of $80.2 \%$ and $74.3 \%$ were obtained using $0.1 \%$ colchicine concentration. All of the 21 entries ( 5 annual diploids and their induced tetraploids as M. lupulina, $M$. radiata, $M$. rijidula, $M$. truncatula, $M$. turbinata, and 3 populations of perennial diploid of M. sativa ssp. Caerulea (Karaj1, Karaj2 and Tehran) and their induced tetraploids and 5 commercial tetraploid alfalfa cultivars (Bami, Hamadani, Baghdadi, Ghareyongeh and Renger) grown in pots in a glasshouse experiment using completely randomized design with five replications in 2018 in Ahvaz, Iran. Data were collected for leaf length, leaf width, shoot and root length, seedling weight, shoot weight, root weight, branch number, leaf area index (LAI) and water use efficiency (WUE). Result of mean comparisons between three groups ( $2 \mathrm{x}$, induced $4 \mathrm{x}$ and controls $4 \mathrm{x}$ ), showed that both groups of induced and natural tetraploids had significantly higher mean values for all the traits except leaf length, shoot length and root length than that for diploids. For the latter traits there were no significant differences between $2 \mathrm{x}$ and induced $4 x$. On the overall, the induced $4 x$ had $60 \%, 62 \%, 68 \%, 65 \%, 22 \%, 109 \%$ and $47 \%$ higher mean values than their parental $2 \mathrm{x}$ for seedling weight, shoot weight, root weight, LAI, WUE and branch number, respectively. It was concluded that increasing ploidy level provides plant breeders with a promising tool in the breeding improve new varieties suited for future climate scenarios.
\end{abstract}

Keywords: ploidy level, colchicine, morphological traits, annual Medicago, perennial Medicago. 


\section{INTRODUCTION}

Alfalfa (Medicago sativa) is a strategic and important forage species for animal feeding. A limited number of Medicago species are cultivated for animal uses or for breeding improved varieties. Among these species, Medicago sativa is widespread in the most parts of the world and its wild forms are rarely available. Commercial varieties of $M$. sativa are perennial cross-pollinated autotetraploid $(2 \mathrm{n}=4 \mathrm{x}=32)$, with Tetrasomic inheritance. M. sativa has both diploid and tetraploid forms (Lapiña et al., 2011). The sub species of Caerulea is a perennial and diploid form $(2 \mathrm{n}=2 \mathrm{x}=16)$. Theoretically, conventional alfalfa has been evolved by sexual polyploidy, which is equivalent to crossing non-reduced (2x) gametes present in diploid species (Bauchan and Hossain, 1997; Rosellini et al., 2016; Pfeiffer and Bingham, 1983). Caerulea's germplasm has the unused potential of being selected as a perennial, sustainable, drought-resistant and soil improving and pasture rehabilitation (Li et al., 2010).

Annual alfalfas are more resistant to plant pests than perennial alfalfa (Bauchan and Azhar, 1998) and can be used in breeding programs as a genetic source to fungal and pest diseases resistance (Yaege and Stuteville, 2000), cold resistance and resistance to adverse and acidic soil conditions (Gillespie, 1989). Annual alfalfas through fertility and improved physical quality, nitrogen fixation, increased organic carbon of soils (Dalal et al., 1995) have a positive effect on grain yield of further grain crops. In addition, with the development of annual alfalfa cultivation, significant amounts of forage can be obtained. Annual alfalfa can grow in summer and fall and planted in rotation with wheat. They also prevent soil erosion (Biederbeck et al., 1993; Badaroddin and Meyer, 1990; Mirzaei Nodoushan, 2001). For many years, common alfalfa has been improved based on the classic plant breeding program. Alfalfa varieties are usually synthetic varieties; Developed by crossing of selected heterozygous parents and their offspring have advanced over three or four generations of seed proliferation (Rowe and Hill, 1999).

Duplication of the plant genomes, or polyploidy induction, which leads to changes in some traits, especially in horticultural, pharmaceutical and agronomic plant species, is based on the application of different drugs such as colchicine, new dinitroanilines, phosphorothioamidates oryzaline, and triflurarin etc. (Melnychuk et al, 2020; Niazian et al, 2020; Su-Jin et al, 2020; Touchell et al, 2020). Colchicine still remains the most efficient and clearly the most preferred and the most used anti mitotic agents because of its widely successful mitosis inhibition ability (Touchell et al, 2020), and for its advantages such as high percentage of viability (Melnychuk et al, 2020) and because of its widely successful mitosis inhibition ability, high solubility in water and ethyl alcohol and heat stability, ability to be autoclaved and easily applied to plant tissues solutions. Therefor reduce the use of additional solvents, it is heat-stable, and can be autoclaved and easily applied to plant tissues (Touchell et al, 2020).

In the context of successful sexual autopolyploidy induction (by crossing (in alfalfa species, a comprehensive research was conducted by Rosellini et al. (2016). Osborn et al., (2003) in their review concluded that a novel variation in polyploids could involve changes in gene expression through increased variation in dosageregulated gene expression, altered regulatory interactions, and rapid genetic and epigenetic changes. Mirzaei Nodushan, (2001) reported that induction of polyploidy in self-pollinated and annual species is likely to improve their morphological and physiological properties and probably can facilitate the adequate gene transfer.

There are some reports on phylogeny of domestic and foreign populations of Medicago genus in Iran. Ghanavati et al. (2005) in study of Genetic diversity of 22 species of genus Medicago collected from Iranian natural habitat using RAPD marker generated a phylogenetic tree with 5 main cluster. Populations of M. aculeala, M.constricta, M.rigiduloidos and M. rigidula with hard pod walls and spongy texture were classified in one cluster. Populations of M. sauvagei, M. laciniata and M. polymorpha which had soft and flexible pod walls were classified together in a separate cluster. In another experiment Ghanavat (2010) in phylogenetic analysis of 23 species of Medicago based on 90 morphological characteristics by maximum parsimony approach, observed the most relationships between $M$. rugosa and M. scutellata, M. sativa and M. lupulina, M. coronata and M. minima, M. rigidula and M. rigiduloides, M. polymorpha and M. arabica, M. tornata and M. turbinata. Salimpour (2012) in phylogenetic analysis of 23 species of alfalfa, the most phylogenetical relationships was observed between $M$. rugosa and M. scutellata, M. sativa and M. lupulina, M. coronata and M. minima, M. rigidula and M. rigiduloides, $M$. polymorpha and $M$. arabica, $M$. tornata and $M$ turbinata. This information can be used in determining the dgree of success of inter-specific hybridization between different species in Medicago genus.

There are many comparative cytogenetic analyses between diploid and tetraploid perennial medics (Yu et al. 2017). But there are few published reports of comparative cytogenetic analysis between perennial and annual diploid medics and their induced tetraploids. The aim of this study was to generate the best populations of annual and 
perennial diploid medics using polyploidy breeding after induction by colchicine treatment and to compare changes of morpho-physiological traits between diploids $2 \mathrm{x}$ and induced $4 \mathrm{x}$ species and commerical $4 \mathrm{x}$ alfalfa cultivars.

\section{MATERIALS AND METHODS:}

In this study, seeds of five annual diploid alfalfa were provided from natural resource gene bank of the Institute of Forests and Rangelands, Tehran, Iran (Table 1). At the same time, seeds of three perennial diploid were provided from College of Agriculture, Tehran University and seeds of five commercial varieties were obtained from Pakan Seed Company, Isfahan, Iran.

Prior to seed sowing, seeds were scarified mechanically with sand paper and then sterilized with a benomyl fungicide. Seeds of five annual diploid medics $(M$. lupulina, M. radiate, M. rigidula, $M$. truncatula, $M$. turbinate) and three perennial diploid Medicago sativa ssp. Caerulea populations (Karaj1, Karaj2 and Tehran) were sown in a mixture of peat moss and field soil at a ratio of 2: 1 in plastic pots with $17 \mathrm{~cm}$ diameter. Pots were kept in $20-25^{\circ} \mathrm{C}$ glasshouses and were irrigated regularly. About three months after sowing, 20 rooted single node cuttings from each of the young plants of diploid seedlings in mitosis stage subjected to three concentrations of colchicine solution (0.1, 0.5 , and $1 \%)$ using dropper method. A drop of colchicine in the lateral bud was put and was repeated for four days after drying or being absorbed and after 15 days, the viability of cuttings was evaluated. The survival rate of the plants was calculated based on the number of well-established plants on the total number of cuttings treated in all the species studied. The induced tetraploids were identified using the usual method of chromosomes counting in the metaphase cells of root tip meristems with having a minimum of 10 metaphase plate mitosis for each species/ populations. The highest induced tetraploidy (80.2\%) was obtained using $0.1 \%$ colchicine concentration. Then, all of the 21 entries: 5 annual diploids and 5 induced tetraploids, 3 perennial diploids and 3 induced tetraploids of Medicago sativa ssp. Caerulea and 5 commercial tetraploid alfalfa cultivars as control (Baghdadi, Bami, Hmamadani, Renger, Ghareyounje) grown in pots in a glasshouse using completely randomized design with five replications in 2018 in Ahvaz, Iran.

In diploid and induced tetraploids (using $0.1 \%$ colchicine) and commercial tetraploids, data collected for leaf length $(\mathrm{mm})$, leaf width $(\mathrm{mm})$, shoot length $(\mathrm{cm})$, root length $(\mathrm{cm})$, shoot weight per plant $(\mathrm{g})$, root weight $(\mathrm{g})$, seedling weight $(\mathrm{g})$ and, branches number per seedling, leaf area index (LAI) and water use efficiency (WUE). After about two months after growth of seedlings and induction polyploidy plants, middle leaves of seedlings were selected for measurements. LAI measurements were performed manually using leaf plot and shadow measurements using $\mathrm{mm}$ checkerboard paper. The WUE was estimated as, where: $Y=$ water beneficially used (seedling dry weight) and $\mathrm{W}=$ total amount of water that was estimated for each plant during the growth period. The data were analyzed by completely randomized design experiment and means were compared using Tukey's test. The SAS9.1 software was used for analysis of variance and mean comparisons.

\section{RESULTS}

In the present study the effects of polyploidy induction on morph-physiological traits in five annual and three perennial diploid medics were assessed and they were subjected to different concentrations of colchicine solution $(0.1 \%, 0.5 \%, 1 \%$ and $2 \%)$ in mitosis stage. The highest survival rate $(80.2 \%)$ and tetraploidy induction (74.3\%) were obtained in $0.1 \%$ colchicine concentration.

Result of analysis of variance showed a significant difference between all of the 21 entries for all of traits $(\mathrm{P}<0.01)$. Such differences were predictable due to the origin and genome differences and ploidy levels between populations (Table 2). The Maximum of coefficient of variation (CV\%) was $21.77 \%$ for root length and minimum was $11.87 \%$ for seedling weight, indicating that good accuracy of the experiment in evaluating traits.

Table 1. Name, Specifications and Origin of Annual Diploid alfalfa.

\begin{tabular}{|c|c|c|c|c|c|c|}
\hline Scientific name & Code & Origin of seed & Province & Altitude m & Latitude & Longitude \\
\hline Medicago turbinate & 24646 & Kermanshah & Kermanshah & 1200 & $34^{\circ} 08^{\prime} 00^{\prime \prime}$ & $46^{\circ} 10^{\prime} 00^{\prime \prime}$ \\
\hline Medicago rigidula & 45078 & Dallahou & Kermanshah & 1213 & $34^{\circ} 23^{\prime} 34^{\prime \prime}$ & $46^{\circ} 03^{\prime} 31^{\prime \prime}$ \\
\hline Medicago radiate & 44137 & Izzeh & Khozestan & 767 & $35^{\circ} 36^{\prime} 07^{\prime \prime}$ & $39^{\circ} 03^{\prime} 78^{\prime \prime}$ \\
\hline Medicago lupulina & 20307 & Unknown & & & & \\
\hline Medicago truncatula & 20587 & Unknown & & & & \\
\hline
\end{tabular}


Mean comparisons were made between average over three groups of $2 \mathrm{x}$, induced $4 \mathrm{x}$ and controls $\mathrm{cv}$. $4 \mathrm{x}$ (Table 3). Result showed that the higher values of all traits were observed in control (cv. $4 \mathrm{x}$ ) followed by induced tetraploid in terms of leaf width, shoot length, shoot weight, seedling weight, WUE and branches number. In the other word, there were no significant differences between control cv. $4 \mathrm{x}$ and induced tetraploids for the latter traits. However, for leaf length, root length, root weight and LAI, the means of induced tetraploids were significantly lower than that for controls (cv. 4x). The overall means of diploids were ranked as third place, however, for leaf length and root length. There was no significant differences between $2 \mathrm{x}$ and induced $4 \mathrm{x}$. for other traits as: leaf width, shoot weight, root weight, seedling weight, LAI, WUE and branch number, the means of induced tetraploids were significantly higher than diploids (Table 3).

A separate mean comparisons were made among only naturally tetraploids varieties (Table 4). Result showed Baghdadi cv. had higher mean values for all of traits except root length and root weight. For these two traits, the higher values were observed in Ghareyounja cv. and for other traits, the Hamadani cv. ranked in the third place (Table 4 ).

Mean comparison were made between populations separately for diploids and induced tetraploids (Tables 5 and 6). For diploid populations, the higher values of WUE, LAI, root and shoot weight, seedling weight, root and shoot length, leaf size were obtained in M. truncatula $2 \mathrm{x}$ followed by M lupulina $2 \mathrm{x}$ as the second place. Both species are annual (Table 6).
In comparisons between perennial diploids, there was no significant differences between Tehran Karaj1 and Karaj2 2x for WUE, seedling, shoot weight, root and shoot length and leaf width. For branch number the higher value was obtained in Tehran 2x (Table 5). Similarly, in comparisons between perennial induced tetraploids Tehran 4x, ranked in the first class than two other induced perennial populations in terms of the morphological traits (Table 5 and 6).

In comparisons between annual induced tetraploids, the highest values of all of traits except of LAI and branches number were observed in $M$ trancatula 4x. Similarly, M. lupulina $4 \mathrm{x}$ in terms of leaf width, root weight, LAI, branches number was ranked in the first class and for the shoot and root length, shoot weight and seedling weight it was ranked as the second class.

In comparisons of total average of $2 \mathrm{x}$ and total average of induced $4 \mathrm{x}$ groups, result showed in $M$. radiate by increasing ploidy level, leaf length and leaf width decreased by $12 \%$ and $15 \%$, respectively. In contrast, for $M$. rigidula the leaf length and leaf width of the $4 \mathrm{x}$, increased by 15 and $42 \%$ than $2 x$, respectively. In the other diploid species, the increase in ploidy level showed no significant effect on leaf size, but a decrease in root and shoot length was observed in all $2 x$ species ranging from 7 to $30 \%$ for shoot length and between 15 and $51 \%$ for roots length. Thus, root weight and WUE value in $4 \mathrm{x}$ were higher than twice that of $2 \mathrm{x}$. In contrast, low increase was observed for LAI (Table 5 and 6).

In overall, there were no significant differences between $2 \mathrm{x}$ and $4 \mathrm{x}$ for leaf size and LAI. The induced $4 \mathrm{x}$ had $25 \%$ and $38 \%$ lower values than $2 \mathrm{x}$ for Shoot and

Table 2. Analysis of variance studied traits in 23 medic species/populations.

\begin{tabular}{|c|c|c|c|c|c|c|c|c|c|c|c|}
\hline SOV & DF & $\begin{array}{l}\text { Leaf } \\
\text { length }\end{array}$ & $\begin{array}{c}\text { Leaf } \\
\text { width }\end{array}$ & $\begin{array}{l}\text { Shoot } \\
\text { length }\end{array}$ & $\begin{array}{l}\text { Root } \\
\text { length }\end{array}$ & $\begin{array}{c}\text { Seedling } \\
\text { weight }\end{array}$ & $\begin{array}{l}\text { Shoot } \\
\text { weight }\end{array}$ & $\begin{array}{l}\text { Root } \\
\text { weight }\end{array}$ & $\begin{array}{l}\text { Leaf area } \\
\text { index }\end{array}$ & $\begin{array}{l}\text { Water use } \\
\text { efficiency }\end{array}$ & $\begin{array}{l}\text { Branch } \\
\text { number }\end{array}$ \\
\hline Populations & 20 & $30.17^{\star *}$ & $39.07^{\star *}$ & $1074.9^{* *}$ & $966.5^{\star *}$ & $0.476^{* *}$ & $0.712^{\star *}$ & $0.039^{* *}$ & $3.26^{* *}$ & $0.384^{\star *}$ & $583.7^{\star *}$ \\
\hline Error & 79 & 4.75 & 3.73 & 8.63 & 13.30 & 0.006 & 0.012 & 0.002 & 0.11 & 0.010 & 13.08 \\
\hline CV\% & & 15.49 & 17.49 & 14.01 & 21.77 & 11.87 & 12.51 & 21.07 & 14.87 & 16.52 & 15.99 \\
\hline
\end{tabular}

** $=$ Significant at the $1 \%$ probability level.

Table 3. Means Comparison of morpho-physiological traits based on total ploidy levels in all studied alfalfa species.

\begin{tabular}{|c|c|c|c|c|c|c|c|c|c|c|}
\hline Ploidy levels & $\begin{array}{c}\text { Leaf } \\
\text { length } \\
\mathrm{Mm}\end{array}$ & $\begin{array}{c}\text { Leaf } \\
\text { width } \\
\text { mm }\end{array}$ & $\begin{array}{c}\text { Shoot } \\
\text { length } \\
\mathrm{cm}\end{array}$ & $\begin{array}{c}\text { Root } \\
\text { length } \\
\mathrm{cm}\end{array}$ & $\begin{array}{l}\text { seedling } \\
\text { Weight } \\
\text { g/plant }\end{array}$ & $\begin{array}{l}\text { shoot } \\
\text { weight } \\
\text { g/plant }\end{array}$ & $\begin{array}{c}\text { Root } \\
\text { weight } \\
\text { g/plant }\end{array}$ & $\begin{array}{c}\text { Leaf area } \\
\text { index }\end{array}$ & $\begin{array}{l}\text { Water use } \\
\text { efficiency }\end{array}$ & $\begin{array}{l}\text { Branch } \\
\text { number }\end{array}$ \\
\hline Perennial 4x (Control) & $15.88 \mathrm{a}$ & $11.96 \mathrm{a}$ & $26.30 \mathrm{a}$ & $25.51 \mathrm{a}$ & $1.08 \mathrm{a}$ & $0.77 \mathrm{a}$ & $0.31 \mathrm{a}$ & $2.96 \mathrm{a}$ & $0.26 \mathrm{a}$ & $26.04 \mathrm{a}$ \\
\hline Diploids $2 \mathrm{x}$ & $13.02 \mathrm{~b}$ & $9.90 \mathrm{~b}$ & $18.97 \mathrm{~b}$ & $14.46 \mathrm{~b}$ & $0.63 \mathrm{~b}$ & $0.47 \mathrm{~b}$ & $0.16 \mathrm{c}$ & $1.89 \mathrm{c}$ & $0.11 \mathrm{~b}$ & $17.64 \mathrm{~b}$ \\
\hline Induced tetraploids & $14.23 \mathrm{~b}$ & $11.70 \mathrm{a}$ & $20.33 \mathrm{ab}$ & $14.79 \mathrm{~b}$ & $1.02 \mathrm{a}$ & $0.76 \mathrm{a}$ & $0.27 \mathrm{~b}$ & $2.31 \mathrm{~b}$ & $0.23 \mathrm{a}$ & $25.68 \mathrm{a}$ \\
\hline
\end{tabular}

Means with similar letters in each column has no significant difference at $5 \%$ probability level by Tukey test. 
Table 4. Means Comparison of morpho-physiological traits in perennial alfalfa cultivars.

\begin{tabular}{|l|c|c|c|c|c|c|c|c|c|c|}
\hline $\begin{array}{l}\text { Commercial } \\
\text { Varieties }\end{array}$ & $\begin{array}{c}\text { Leaf } \\
\text { length } \\
\mathrm{mm}\end{array}$ & $\begin{array}{c}\text { Leaf } \\
\text { width } \\
\mathrm{mm}\end{array}$ & $\begin{array}{c}\text { Shoot } \\
\text { length } \\
\mathrm{cm}\end{array}$ & $\begin{array}{c}\text { Root } \\
\text { length } \\
\mathrm{cm}\end{array}$ & $\begin{array}{c}\text { Seedling } \\
\text { weight } \\
\text { g/plant }\end{array}$ & $\begin{array}{c}\text { Shoot } \\
\text { weight } \\
\text { g/plant }\end{array}$ & $\begin{array}{c}\text { Root } \\
\text { weight } \\
\text { g/plant }\end{array}$ & $\begin{array}{c}\text { Leaf } \\
\text { area } \\
\text { index }\end{array}$ & $\begin{array}{c}\text { Water use } \\
\text { efficiency }\end{array}$ & $\begin{array}{c}\text { Branch } \\
\text { number }\end{array}$ \\
\hline Baghdadi & $19.60 \mathrm{a}$ & $13.00 \mathrm{a}$ & $39.18 \mathrm{a}$ & $27.54 \mathrm{~b}$ & $1.32 \mathrm{ab}$ & $1.07 \mathrm{a}$ & $0.25 \mathrm{~b}$ & $3.43 \mathrm{a}$ & $0.42 \mathrm{a}$ & $37.80 \mathrm{a}$ \\
\hline Bami & $14.10 \mathrm{~b}$ & $10.90 \mathrm{a}$ & $18.30 \mathrm{c}$ & $18.90 \mathrm{c}$ & $0.72 \mathrm{c}$ & $0.46 \mathrm{c}$ & $0.26 \mathrm{~b}$ & $2.00 \mathrm{~b}$ & $0.17 \mathrm{c}$ & $22.80 \mathrm{~b}$ \\
\hline Ghareyounje & $14.70 \mathrm{~b}$ & $11.50 \mathrm{a}$ & $29.18 \mathrm{~b}$ & $32.48 \mathrm{a}$ & $1.27 \mathrm{~b}$ & $0.91 \mathrm{~b}$ & $0.35 \mathrm{a}$ & $3.30 \mathrm{a}$ & $0.29 \mathrm{~b}$ & $18.40 \mathrm{bc}$ \\
\hline Hamadani & $15.60 \mathrm{ab}$ & $13.00 \mathrm{a}$ & $26.46 \mathrm{~b}$ & $27.68 \mathrm{~b}$ & $1.45 \mathrm{a}$ & $1.07 \mathrm{a}$ & $0.38 \mathrm{a}$ & $3.25 \mathrm{a}$ & $0.31 \mathrm{~b}$ & $35.00 \mathrm{a}$ \\
\hline Renger & $15.40 \mathrm{~b}$ & $11.40 \mathrm{a}$ & $18.38 \mathrm{c}$ & $20.96 \mathrm{c}$ & $0.63 \mathrm{c}$ & $0.35 \mathrm{c}$ & $0.28 \mathrm{~b}$ & $2.82 \mathrm{ab}$ & $0.13 \mathrm{c}$ & $16.20 \mathrm{c}$ \\
\hline
\end{tabular}

Means with similar letters in each column has no significant difference at $5 \%$ probability level by Tukey test

Table 5. Mean comparison of diploid Medicago species and their induced tetraploids for Leaf length, leaf width, shoot length, root length and seedling weight.

\begin{tabular}{|c|c|c|c|c|c|c|c|c|c|c|}
\hline \multirow{2}{*}{ Populations } & \multicolumn{2}{|c|}{$\begin{array}{l}\text { Leaf length } \\
\text { mm }\end{array}$} & \multicolumn{2}{|c|}{$\begin{array}{l}\text { Leaf width } \\
\text { mm }\end{array}$} & \multicolumn{2}{|c|}{$\begin{array}{l}\text { Shoot length } \\
\mathrm{cm}\end{array}$} & \multicolumn{2}{|c|}{$\begin{array}{l}\text { Root length } \\
\mathrm{cm}\end{array}$} & \multicolumn{2}{|c|}{$\begin{array}{l}\text { Seedling weight } \\
\text { g/plant }\end{array}$} \\
\hline & $2 \mathrm{x}$ & $4 \mathrm{x}$ & $2 \mathrm{x}$ & $4 \mathrm{x}$ & $2 \mathrm{x}$ & $4 \mathrm{x}$ & $2 \mathrm{x}$ & $4 \mathrm{x}$ & $2 \mathrm{x}$ & $4 \mathrm{x}$ \\
\hline M. sativa (Karaj1) & $12.20 \mathrm{~b}$ & $12.43 \mathrm{c}$ & $10.60 \mathrm{bc}$ & $10.57 \mathrm{~b}$ & $14.64 \mathrm{~b}$ & $11.30 \mathrm{~b}$ & $13.00 \mathrm{~b}$ & $8.81 b$ & $0.59 \mathrm{c}$ & $0.75 \mathrm{~cd}$ \\
\hline M. sativa (Karaj2) & $17.00 \mathrm{a}$ & $16.86 \mathrm{a}$ & $15.00 \mathrm{a}$ & $14.86 \mathrm{a}$ & $15.54 \mathrm{~b}$ & $10.83 \mathrm{~b}$ & $8.60 \mathrm{~b}$ & $5.43 \mathrm{~b}$ & $0.53 \mathrm{c}$ & $0.88 \mathrm{bc}$ \\
\hline M. sativa (Tehran) & $12.40 \mathrm{~b}$ & $12.00 \mathrm{c}$ & $10.60 \mathrm{bc}$ & $10.83 \mathrm{~b}$ & $16.78 \mathrm{~b}$ & $12.47 \mathrm{~b}$ & $9.50 \mathrm{~b}$ & $5.92 \mathrm{~b}$ & $0.60 \mathrm{bc}$ & $1.01 \mathrm{~b}$ \\
\hline M lupulina & $12.60 \mathrm{~b}$ & $12.86 \mathrm{c}$ & $13.60 \mathrm{ab}$ & $13.43 \mathrm{a}$ & $14.54 \mathrm{~b}$ & $10.69 \mathrm{~b}$ & $11.92 \mathrm{~b}$ & $5.77 \mathrm{~b}$ & $0.68 \mathrm{~b}$ & $0.96 \mathrm{~b}$ \\
\hline M. radiata & $13.60 \mathrm{ab}$ & $12.00 \mathrm{c}$ & $9.20 \mathrm{~cd}$ & $7.80 \mathrm{c}$ & $16.78 \mathrm{~b}$ & $11.86 \mathrm{~b}$ & $11.28 \mathrm{~b}$ & $7.80 \mathrm{~b}$ & $0.61 \mathrm{bc}$ & $0.90 \mathrm{bc}$ \\
\hline M. Rigidula & $11.60 \mathrm{bc}$ & $13.40 \mathrm{bc}$ & $6.60 \mathrm{de}$ & $9.40 \mathrm{bc}$ & $15.10 \mathrm{~b}$ & $11.48 \mathrm{~b}$ & $12.10 \mathrm{~b}$ & $8.84 \mathrm{~b}$ & $0.64 \mathrm{~b}$ & $0.93 \mathrm{~b}$ \\
\hline M. truncatula & $15.00 \mathrm{ab}$ & $15.75 \mathrm{ab}$ & $12.80 \mathrm{~b}$ & $13.25 \mathrm{a}$ & $54.52 \mathrm{a}$ & $50.44 \mathrm{a}$ & $51.58 \mathrm{a}$ & $40.63 \mathrm{a}$ & $1.32 \mathrm{a}$ & $1.54 \mathrm{a}$ \\
\hline M. turbinata & $15.80 \mathrm{ab}$ & $16.25 \mathrm{a}$ & $8.80 \mathrm{~d}$ & $9.50 \mathrm{bc}$ & $14.86 \mathrm{~b}$ & $12.75 \mathrm{~b}$ & $11.08 \mathrm{~b}$ & $9.33 \mathrm{~b}$ & $0.43 \mathrm{~cd}$ & $0.61 \mathrm{~d}$ \\
\hline Average & 13.78 & 13.94 & 10.90 & 11.21 & $20.35 \mathrm{~A}$ & $16.48 \mathrm{~B}$ & $16.13 \mathrm{~A}$ & $11.57 \mathrm{~B}$ & $0.68 \mathrm{~B}$ & $0.95 \mathrm{~A}$ \\
\hline
\end{tabular}

Means with similar letters in each column has no significant difference at $5 \%$ probability level by Tukey test.

Table 6. Mean comparison of diploid medicago species and their induced tetraploids for shoot weight, root weight, LAI, WUE and branch number.

\begin{tabular}{|c|c|c|c|c|c|c|c|c|c|c|}
\hline \multirow[t]{2}{*}{ Population name } & \multicolumn{2}{|c|}{$\begin{array}{l}\text { Shoot weight } \\
\text { g/plant }\end{array}$} & \multicolumn{2}{|c|}{$\begin{array}{l}\text { Root weight } \\
\text { g/plant }\end{array}$} & \multicolumn{2}{|c|}{$\begin{array}{l}\text { Leaf area } \\
\text { index }\end{array}$} & \multicolumn{2}{|c|}{$\begin{array}{l}\text { Water use } \\
\text { efficiency }\end{array}$} & \multicolumn{2}{|c|}{$\begin{array}{l}\text { Branch } \\
\text { number }\end{array}$} \\
\hline & $2 \mathrm{x}$ & $4 \mathrm{x}$ & $2 \mathrm{x}$ & $4 \mathrm{x}$ & $2 \mathrm{x}$ & $4 \mathrm{x}$ & $2 \mathrm{x}$ & $4 \mathrm{x}$ & $2 \mathrm{x}$ & $4 \mathrm{x}$ \\
\hline M. sativa (Karaj1) & $0.38 \mathrm{~cd}$ & $0.48 \mathrm{c}$ & $0.20 \mathrm{~b}$ & $0.27 \mathrm{ab}$ & $2.10 \mathrm{bc}$ & $2.18 \mathrm{~d}$ & $0.08 \mathrm{de}$ & $0.17 \mathrm{c}$ & $15.00 \mathrm{c}$ & $17.14 \mathrm{c}$ \\
\hline M. sativa (Karaj2) & $0.41 \mathrm{~cd}$ & $0.63 b$ & $0.12 \mathrm{c}$ & $0.25 \mathrm{ab}$ & $2.21 \mathrm{bc}$ & $2.33 \mathrm{c}$ & $0.09 \mathrm{~d}$ & $0.18 \mathrm{c}$ & $16.60 \mathrm{c}$ & $19.00 \mathrm{c}$ \\
\hline M. sativa (Tehran) & $0.48 \mathrm{bc}$ & $0.74 \mathrm{~b}$ & $0.12 \mathrm{c}$ & $0.27 \mathrm{ab}$ & $1.53 \mathrm{c}$ & $1.65 \mathrm{f}$ & $0.11 \mathrm{~cd}$ & $0.21 \mathrm{bc}$ & $16.40 \mathrm{c}$ & $18.00 \mathrm{c}$ \\
\hline M. lupulina & $0.55 \mathrm{~b}$ & $0.71 b$ & $0.13 c$ & $0.25 \mathrm{ab}$ & $3.22 \mathrm{a}$ & $3.41 \mathrm{a}$ & $0.17 \mathrm{~b}$ & $0.23 \mathrm{~b}$ & $35.60 \mathrm{a}$ & $44.00 \mathrm{a}$ \\
\hline M. radiata & $0.47 \mathrm{bc}$ & $0.67 b$ & $0.14 \mathrm{bc}$ & $0.23 \mathrm{ab}$ & $1.35 \mathrm{c}$ & $1.45 \mathrm{~g}$ & $0.10 \mathrm{~d}$ & $0.18 \mathrm{c}$ & $13.20 \mathrm{c}$ & $18.60 \mathrm{c}$ \\
\hline M. Rigidula & $0.46 \mathrm{bc}$ & $0.64 \mathrm{~b}$ & $0.18 \mathrm{bc}$ & $0.29 \mathrm{ab}$ & $1.32 \mathrm{c}$ & $1.42 \mathrm{~g}$ & $0.13 \mathrm{cb}$ & $0.18 \mathrm{c}$ & $14.40 \mathrm{c}$ & $17.60 \mathrm{c}$ \\
\hline M. truncatula & $0.95 \mathrm{a}$ & $1.22 \mathrm{a}$ & 0.37 a & $0.31 \mathrm{a}$ & $2.82 \mathrm{ab}$ & $2.96 \mathrm{~b}$ & $0.24 \mathrm{a}$ & $0.37 \mathrm{a}$ & $28.80 \mathrm{~b}$ & $37.08 \mathrm{~b}$ \\
\hline M. turbinata & $0.29 \mathrm{~d}$ & $0.40 \mathrm{c}$ & $0.14 \mathrm{bc}$ & $0.21 \mathrm{~b}$ & $1.64 \mathrm{c}$ & $1.78 \mathrm{e}$ & $0.07 \mathrm{de}$ & $0.11 \mathrm{~d}$ & $12.80 \mathrm{c}$ & $16.50 \mathrm{c}$ \\
\hline Average & $0.50 \mathrm{~B}$ & $0.69 \mathrm{~A}$ & $0.18 \mathrm{~B}$ & $0.26 \mathrm{~A}$ & $2.02 \mathrm{~B}$ & $2.15 \mathrm{~A}$ & $0.12 \mathrm{~B}$ & $0.20 \mathrm{~A}$ & $19.10 \mathrm{~B}$ & $23.49 \mathrm{~A}$ \\
\hline
\end{tabular}

Means with similar letters in each column has no significant difference at $5 \%$ probability level by Tukey test. 
root length, respectively. In contrast, the induced $4 \mathrm{x}$ had $40 \%, 38 \%, 44 \%, 65 \%$ and $23 \%$ higher values than $2 \mathrm{x}$ for seedling weight, shoot weight, root weight, WUE and branch number, respectively (Tables 5 and 6).

\section{DISCUSSION}

In this study, we found higher ploidy induction at the lower colchicine concentration (0.1\%). Colchicine still remains the most efficient and clearly the most preferred and the most used anti mitotic agents because of its widely successful mitosis inhibition ability (Touchell et al, 2020). The others anti-mitotic agents such as dinitroanilines and etc.. may also increase the ploidy levels. In addition, increasing of the ploidy levels can probably be an appropriate solution for crossing of various alfalfa species and increasing their genetic diversity and transferring desirable traits. It seems polyploidy induction in self-pollinated annual medic species are likely to improve the morphological and physiological characteristics in these species.

The result indicated that induced $4 \mathrm{x}$ had $25 \%$ and $38 \%$ lower values for the shoot and root length than $2 \mathrm{x}$, respectively, averaged over all of species. The reduction in root length of $M$. truncatula was higher than that of other species. The results of the present study were in line with results of Pickens (2004) showing shorter shoots of colchicine treated plants compared to nottreated controls.

Overall, the induced $4 \mathrm{x}$ had $60 \%, 62 \%, 68 \%, 65 \%$, $22 \%, 109 \%$ and $47 \%$ higher mean values than their $2 \mathrm{x}$ for seedling weight, shoot weight, root weight, LAI, WUE and branch number, respectively. In $M$. truncatula, the seedling weight of induced $4 \mathrm{x}$ was $16 \%$ higher than $2 \mathrm{x}(1.32$ vs. $1.54 \mathrm{~g} / \mathrm{p})$. This result was in agreement with the result of the polyploidy induction in Catharanthus roseus using colchicine solution that significantly increased the seedling weight of tetraploid plants compared to diploid plants (Hosseini et al. 2013).

Shoot weight was higher in all induced species than the diploids. The higher values of shoot weight among all of population were obtained in M. truncatula. In this species, the value of induced $4 \mathrm{x}$ was $28 \%$ higher than its parental $2 \mathrm{x}$. This result was in line with the Staji et al. (2017) that found polyploidy induction significantly increased shoot weight in Salvia leriifolia. Tavan (2014) in some endemic species of Thyme genus in Iran found that increase in ploidy level was associated with an increase in shoot weight. Similarly, Bagheri and Mansouri (2015) in cannabis (Cannabis sativa L.) found that the root and seedling weight of polyploid plants were significantly increased than diploid plants. In our study, the higher values of LAI were obtained in M. lupulina. LAI was higher in all induced species than the diploids. In the overall average over all species, the LAI of induced $4 \mathrm{x}$ was $7 \%$ higher than $2 \mathrm{x}$ (2.02 vs. 2.15$)$.

As the ploidy levels increased, the average value of WUE in all studied species increased up to $65 \%$. Contributing factors to WUE are related to climate factors that are essential for water use (evapotranspiration) and water supply (atmospheric rain), management factors for cultivation and operations lead to evaporation reduction from the soil surface (Kafi and Damghani 2001). It seems that M. truncatula has probably been the best choice for polyploidy induction in annual species.

Ploidy changes in cell size are due to an increase in the number of copies of genes and thus an increase in the amount of protein produced (Tsukaya 2013). Nowadays, it has been found that control of morphological traits at the molecular level by ploidy level alteration via genetic (Tsukaya 2013), transcriptomic (Li et al. 2012) and epigenetic (Zeng et al. 2012, Aversano et al. 2012) modification occurs. For example, changes in the genomic dose of polyploids lead to changes in the expression of genes involved in cell cycle, photosynthesis, and cell metabolism (Shi et al. 2015), As a result of autotetraploidy, alterations in the expression of genes related to stress response, hormonal signaling actions, and response to phytohormones are applied Which may lead to a flexible and rapid response to external and internal stimuli (Del Pozo and Ramirez 2014). Slight but pervasive changes in gene expression are probably correlated with large phenotypic differences in autotetraploids (Allario et al. 2013). In some reports, autotetraploidy has caused epigenetic alteration by DNA methylation at the functional genes sites, encoding proteins and at the sequences involved in DNA replication, electron transport chain, and transcriptional regulation (Zeng et al. 2012). In some cases, methylation has been the result of cytosine methylation at the CG and CHG sites (Aversano et al. 2012). probably a combination of chromosome duplication, along with genetic, epigenetic, and transcriptomic effects, can produce morphophysiological differences due to polyploidy induction, as in our experiment (Yang et al. 2011).

\section{CONCLUSION}

In addition to the highest survival rate and most successful induction after colchicine treatment, the induced tetraploid of M. truncatula, among all of evaluated species, showed the highest levels of morpho- 
logical indices. It seems that if the goal of breeding is to increase in economical properties such as seedling weight and WUE etc. It seems that $M$. truncatula probably is the best choice for polyploidy induction in annual species.

All perennial diploids did not show any un-uniformity by increasing ploidy level in this study, the increasing of the ploidy level of agronomic "perennial" tetrapleoids may be a more effective step to achieve superior new cultivars.

In comparing diploid alfalfas, the annual species, showed higher mean values for morphological traits than perennial diploid alfalfas. In comparisons among the three perennial "diploid" populations, Tehran had higher mean values for shoot length, shoot weight, seedling weight and WUE. Therefore, Tehran population is advisable for breeding improve new variety of perennial tetraploid via induce polyploidy. As a result, increasing the ploidy level $2 \mathrm{x}$ to $4 \mathrm{x}$ is a successful way to obtain superior morphological and physiological indices in the studied species and subspecies.

In overall, there were no significant differences between $2 \mathrm{x}$ and $4 \mathrm{x}$ for leaf size and LAI. The induced $4 \mathrm{x}$ had $25 \%$ and $38 \%$ lower values than $2 \mathrm{x}$ for Shoot and root length, respectively. In contrast, the induced $4 \mathrm{x}$ had $40 \%, 38 \%, 44 \%, 65 \%$ and $23 \%$ higher values than $2 \mathrm{x}$ for seedling weight, shoot weight, root weight, WUE and branch number, respectively.

\section{REFERENCES}

Bagheri, M. and Mansouri, H. 2015. Effect of polyploidy induction on some growth parameters in cannabis (Cannabis sativa L.). Plant Process and Function, 4(13): 113-120.

Bauchan, G. R., and Hossain, M. A. 1997. Karyotypic Analysis of C-Banded Chromosomes of Diploid Alfalfa: Medicago sativa ssp. caerulea and ssp. falcata and Their Hybrid. Journal of Heredity, 88(6): 533-537.

Bauchan, G.R. and Azhar, M.H. 1998. Advances in alfalfa cytogenetics. J. Heredity, 89: 191-193.

Biederbeck, V.O. Bouman, O.T. Looman, J. Slinkard, A.E. Bailey, L.D. Rice, W.A and Janzen, H.H. 1993. Productivity of four annual legumes as green manure in dryland cropping systems. Agronomy Journal, 85: 1035-1043.

Ghanavati, F. 2010. Phylogenetic realationships of Medicago species in Iran. Iranian Journal of Crop Sciences. 13(2): 424-435. (In Persian).

Ghanavati, F., Mozafari J, Safaei H, Kazempour Osalu Sh. 2005. Phylogenetic relationships in Iranian medicago genus using RAPD marker. Pajouhesh \& Sazandegi 66 2-12. (In Persian).

Gillespie, D.J. 1989. The development of Murex medic as a new pasture species for acid soils in Australia. Proceedings of the XVI International Grassland Congress. Nice, France. 215-216.

Hosseini, H. Chahrazi, M. Nebati Ahmadi, D. and Mahmoodi Sourestani, M. 2013. Autotetraploid induction in the flower of Rosar (Catharanthus roseus Don) for variation in morphological and phenological characteristics using colchicine treatment. Process and Plant Function, 3(9): 8-1.

Kafi, M. and Mahdavi Damghani, M. 2001. Seed Biology and Crop Yield (translation). Mashhad Academic Publications, Iran (In Persian).

Lapiņa, L. Grauda, D. and Rashal, I. 2011. Characterization of Latvian alfalfa Medicago sativa genetic resources. Acta Biol. Universit. Daugavpil. 11 (2): 134-140.

Li, G. D. Nie, Z. N. Boschma, S. P. Dear, B. S. Lodge, G. M. HayesA, R. C. Clark, B. Hughes, S. J. and Humphries, A. W. 2010. Persistence and productivity of Medicago sativa subspecies sativa, caerulea, falcata and varia accessions at three intermittently dry sites in south-eastern Australia. Crop \& Pasture Science, 61: 645-658.

Li, X. Yu, E. Fan, C. Zhang, C. Fu, T. Zhou, Y. 2012. Developmental, cytological and transcriptional analysis of autotetraploid Arabidopsis. Planta 236: 579596.

Melnychuk O.V., Ozheredov S.P., Rakhmetov D.B. et al. 2020. Induction of polyploidy in giant miscanthus (Miscanthus $\times$ giganteus Greef et Deu.). Proc. Latvian Acad. Sci. Section B. vol 74, 3(726): 20-30.

Mirzaie NodouShan, H. 2001. Annual Alfalfa, (Genetics and Breeding). Institute of Forests and Rangelands Research, publication, Tehran, Iran. 214 pages. (In Persian).

Niazian M., Nalousi A.M. 2020. Artificial polyploidy induction for improvement of ornamental and medicinal plants. Plant Cell Tiss. Organ Cult. 142(3: 447-469.

Osborn, T.C., Brouwer D. and McCoy, T. J. 1997. Molecular marker analysis of alfalfa. PP: 91-109. In: Mc Kersie, B.D. and D.C. Brown (Eds.), Biotechnology and the Improvement of Forage Legumes, CAB International, Oxon, UK.

Pfeiffer, T.W. and Bingham, E.T. 1983. Abnormal meiosis in alfalfa, Medicago sativa- cytology of $2 \mathrm{n}$ egg and $4 \mathrm{n}$ pollen formation. Can J Genet Cytol 25: 107-112.

Pickens, K. A. 2004. In vitro propagation, regeneration attempted tetraploid induction, and agrobacterium- 
mediated transformation of Euphorbia pulchurrima. Doctoral Dissertations University of Tennessee, USA.

Rosellini, D. Ferradini, N. Allegrucci, S. Capomaccio, S. Debora Zago, E. Leonetti, P. Balech, B. Aversano, R. Carputo, D. Reale, L. and Veronesi, F. 2016. Sexual Polyploidization in Medicago sativa L. Impact on the Phenotype, Gene Transcription, and Genome Methylation, G3 (Bethesda). 6(4): 925-938.

Rowe, D. E. and Hill, R. R. 1999. Breeding theory and the development of alfalfa. The Alfalfa Genome. USDAARS, Curtin Road, University Park, PA (www.naaic. org/TAG/TAGpapers/RoweAbs.html).

Salimpour, F. 2012. Phylogenetic study of some species of alfalfa (Medicago) Proceeding of the first national conference on New finding in Cellular and Molecular, Tehran, Iran. (In Persian).

Shi, X. Zhang, C. Ko, D.K. Chen, Z. J. 2015. Genomewide dosage dependent and independent regulation contributes to gene expression and evolutionary novelty in plant polyploids. Molecular Biology and Evolution 32(9): 2351-2366.

Staji, A. Hussein, B. Dehghan, I. Stagei, A. 2017. Evaluation of colchicine treatment on some morphological, physiological and effective materials of Benthleriifolia salvia. Iranian Journal of Medicinal and Aromatic Plants Research Monthly, 33(4): 563-578.

Su-Jin B., Mazharul Islam Md., Hong-Yul K. and KiByung L. 2020. Induction of Tetraploidy in Watermelon with Oryzalin Treatments. Hort. Sci. Tech., 38(3), 385-393.

Tavan, M. 2014. Induction of polyploidy in in vitro culture conditions and its effect on morphological, anatomical and phytochemical characteristics of Iranian Thyme. Thesis for Master's Degree in Horticultural Sciences, Shahid Beheshti University, Iran (In Persian).

Touchell D.H., Palmer I.E., Ranney T.G. 2020. In vitro ploidy manipulation for crop improvement. Front. Plant Sci. 11: 722.

Yaege J.R. and Stuteville. D.L. 2000. Reactions in the annual Medicago core germplasm collection to two isolates of Peronospora trifoliorum from alfalfa plant diseases 84:521-524.

Yu, F., Wang, H., Zhao. Y., Liu, R.. Dou, Q., Dong, J., Wang. T. 2017. Karyotypic evolution of the Medicago complex: sativa-caerulea-falcata inferred from comparative cytogenetic analysis. BMC Evol Bio. 17: 104. 